\section{Født sånn eller blitt sånn eller selvoppfyllende profetier?}

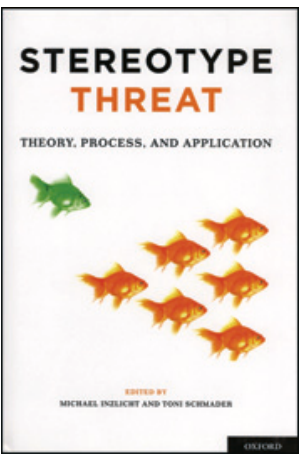

Michael Inzlicht, Toni Schmader, red Stereotype threat

Theory, process, and application. 320 s, tab, ill. Oxford: Oxford University Press, 2012.

Pris GBP 40

ISBN 978-0-19-973244-9

Hva om en kjøreskole arrangerer konkurranse i lukeparkering mellom mannlige og kvinnelige elever? Ikke i tvil om hvem som vinner? Men hvis konkurransen skjer mellom to lag med bare kvinner? Jo, da er det sannsynlig at de fleste kvinnene vil prestere bedre enn de gjorde i den første konkurransen. Hvorfor det er slik? Enkelt sagt, har det med gruppetilhørighet å gjøre. Hvem vi identifiserer oss med, vår sosiale identitet. $\mathrm{Og}$ her kommer begrepet stereotypi inn. Vi er kvinner, menn, kristne, muslimer, svarte, hvite, fattige, rike, håndverkere, intellektuelle og så videre og så videre. Alle bærer vi merkelapper. Og merkelappene definerer stereotypier - intelligente, dumme, tekniske, klønete, helter, skurker. Stereotypier kan være både positivt og negativt ladet; de negative ligger til grunn for fordommene våre.

Hva er så en stereotypitrussel? I akademisk sammenheng dukket begrepet først opp i USA i 1990-årene. Etter hvert er det blitt et eget fagområde og et av de tyngste forskningsfeltene innen moderne sosialpsykologi. I Steretype threat blir de viktigste aspektene ved denne forskningen oppsummert. Boken er redigert av to nestorer innen sosialpsykologi, Michael Inzlicht og Toni Schmader. Den er inndelt i 19 kapitler, det siste er skrevet av Claude Steele, sosialpsykologen som introduserte begrepet i 1995. Forfatterne tar for seg fire områder: Første del omhandler de basale prosessene som «trigger og medierer» hvordan negative stereotypier hindrer prestasjoner. I andre del blir teoretiske modeller som utvider det opprinnelige begrepet drøftet. Den tredje delen beskriver forskning på ulike sosiale grupper der effekten av stereotypitrusler er dokumentert. Siste del tar for seg videreutvikling av teorier og metoder for hvordan negative stereotypier kan motvirkes i akademisk sammenheng.

Mest forskning på dette området er gjort når det gjelder akademiske prestasjoner hos studenter med minoritetsbakgrunn. Tallrike studier har vist at svarte studenter underpresterer i tester der stereotypitrusselen utgjør en faktor i settingen for testen. Blant annet har eksperimentelle studier med avanserte nevropsykologiske metoder vist økt angstnivå og konsentrasjonssvikt i situasjoner der forsøkspersonene risikerer å bekrefte en negativ stereotypi. Det gis også interessante eksempler fra forskning på kjønnsforskjeller. I en test der deltakerne skulle sette sammen et modellhus, skåret kvinner lavere enn menn når det fremgikk at testen var designet av ingeniører, mens de skåret høyere enn menn når det ble opplyst at den var utviklet i et kunstfaglig prosjekt.

Hvordan unngå at stereotypitrusselen påvirker testresultater i negativ retning? Først og fremst ved å være klar over at den er der. Deretter ved å sørge for at både tester og - ikke minst - testsituasjoner er mest mulig nøytrale. Det siste kan kanskje være noe å tenke på ved sykehusenes store medarbeiderundersøkelser og når Legeforeningen vil kartlegge legers trivsel og helse? Vel er det interessant for undersøkeren å se etter kjønns- og aldersforskjeller, men når spørreskjemaene uunngåelig åpner med registrering av kjønn, alder og stilling, er stereotypitrussel introdusert som en feilkilde.
Stereotype threat er velskrevet, lettlest og godt pedagogisk tilrettelagt. Jeg kunne nok tenkt meg flere illustrasjoner og mindre tekst, men innvendingen har antakelig med min egen faglige bakgrunn å gjøre. Alle kapitlene følger samme mal. I likhet med en vitenskapelig artikkel, starter hvert kapittel med et sammendrag og nøkkelord, og avsluttes med konklusjon og en «policy box» samt alfabetisk referanseliste. Til tross for 19 forfattere, fremstår presentasjonen helhetlig. Det er liten grad av overlapping mellom kapitlene, noe som tilsier at de to redaktørene har gjort en god og grundig jobb. Boken er ikke oversatt til norsk, men for målgruppen her i landet spiller neppe det noen rolle. Tilhører norske leger denne målgruppen? At Tidsskriftet har bedt meg om en anmeldelse, skulle kanskje tyde på det?

\section{May Brit Lund}

Lungeavdelingen

Oslo universitetssykehus, Rikshospitalet

\section{Ufullstendig om astma}

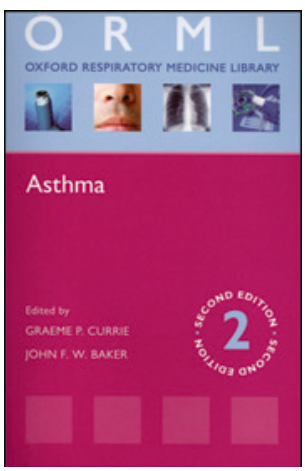

Graeme P. Currie, John F. W. Baker, red. Asthma

2. utg, 149 s, tab, ill. Oxford: Oxford University Press, 2012. Pris GBP 20

ISBN 978-0-19-963891-8

Asthma er en del av «Oxford Respiratory Medicine Library», en serie som tar sikte på å gi klinikere en oppdatering innen viktige lungemedisinske tilstander og problemstillinger. Forfatterne ønsker å gi en kunnskapsbasert gjennomgang av viktige kliniske aspekter ved astma.

Innholdet blir presentert i tre deler. De to første tar på klassisk lærebokvis opp astma hos voksne og barn, og deretter følger flere kapitler som omhandler mer spesifikke problemstillinger - astma hos gravide, astma i allmennpraksis, «vanskelig astma» og mer. Språket er konsist, nærmest i telegramstil, og fulgt av enkle oversiktlige figurer og tabeller.

Forfatterne er britiske leger, og både epidemiologi, behandling og oppfølging er rettet mot britiske forhold som den norske leseren ikke nødvendigvis kjenner til. I tråd med dette er behandlingsalgoritmer hentet fra British Thoracic Society, og ikke fra Global Initiative for Asthma (GINA).

Jeg har vansker med å se hvordan denne boken skal kunne være til nytte for et norsk publikum. Som lærebok og innføring i astmasyndromet er den for kortfattet og forenklet, og den er litt for geografisk avgrenset til å kunne egne seg som astmahåndbok for klinikere. Imidlertid avslører den et behov for en tilsvarende norsk publikasjon.

\section{Rune Nielsen}

Lungeavdelingen

Haukeland universitetssykehus 